\title{
INVESTIGATING THE EFFECT OF DIFFERENT HYDRAULIC CROSS SECTTION OF DENITRIFICATION BEDS ON THE AMOUNT OF EFFLUENT ELECTRICAL CONDUCTIVITY
}

\author{
INVESTIGANDO O EFEITO DE DIFERENTES SEÇÕES \\ TRANSVERSAIS HIDRÁULICAS DE LEITOS DE DESNITRIFICAÇÃO \\ NA QUANTIDADE DE CONDUTIVIDADE ELETRICA DO EFLUENTE
}

\section{Hedieh Ahmadpari}

Graduado em Irrigação e Drenagem, Departamento de Irrigação e Drenagem, Faculdade de Aburaihan, Universidade de Teerã, Irã. Email:

h.ahmadpari@gmail.com

Seyyed Ebrahim Hashemi Garmdareh

Professor Assistente, Departamento de Irrigação e Drenagem, Faculdade de Aburaihan, Universidade de Teerã, Irã. Email: sehashemi@ut.ac.ir

Samira Sadri

Graduado em Engenharia de Recursos Hídricos, Universidade Shahid Chamran de Ahvaz, Irã Email:

samirasadri71@yahoo.com

\section{RESUMO}

As cargas de nitratos da drenagem agrícola para os recursos hídricos superficiais causam sérios problemas de qualidade da água em muitas partes do mundo. Os biorreatores de desnitrificação são uma opção adequada para remover o nitrato da água de drenagem agrícola. Os objetivos deste estudo foram investigar o efeito de diferentes seções transversais hidráulicas de leitos de desnitrificação sobre a quantidade de condutividade elétrica do efluente. Neste estudo, três leitos de desnitrificação foram construídos com seções transversais semicirculares, triangulares e retangulares, preenchidas com lascas de madeira de faia. As amostras foram retiradas das saídas de todos os três leitos a uma profundidade de 25 e $50 \mathrm{~cm}$ do fundo da cama durante dois meses. A condutividade elétrica - (CE) das amostras foi medido usando EC-meter. Após a determinação da CE das amostras, os dados foram analisados por testes $\mathrm{T}$ e univariados. Os resultados mostraram que a forma da seção transversal dos leitos de desnitrificação e a profundidade de saturação tiveram um efeito significativo na $\mathrm{CE}$ e a quantidade de $\mathrm{CE}$ da vazão foi aumentada. Palavras-chave: Nitrato. Secção transversal de leito de desnitrificação. Aparas de madeira.

\section{ABSTRACT}

Nitrate loadings from agricultural drainage to surface water resources cause's serious water quality concerns in many parts of the world. Denitrification bioreactors are suitable option for removing nitrate from agricultural drainage water. The objectives of this study was to investigate the effect of different hydraulic cross sections of denitrification beds on the amount of effluent electrical conductivity (EC). In this study, three denitrification beds were constructed with a semicircular, triangle and a rectangle cross sections, filled with wood chips of beech tree. Samples were taken from the outlets of all three beds at a depth at 25 and $50 \mathrm{~cm}$ from the bottom of the bed for two months. EC of the samples was meassured using EC-meter. After determining the EC of the samples, data were analyzed by T-test and Univariate tests. The results showed that the shape of the cross-section of the denitrification beds and the saturation depth had a significant effect on EC and the amount of EC of the outflow was increased.

Keywords: Nitrate. Denitrification bed cross section. Wood chips. 
Revista Tecnologia e Ambiente, v. 25, 2019, Criciúma, Santa Catarina/SC ISSN Eletrônico 2358-9426 e ISSN Impresso 1413-8131

\section{INTRODUCTION}

Increasing irrigation area and using low quality water cause of increased salinity and waterlogging of land in recent years. Drainage and suitable leaching are the most effective method that can be used todays to prevent land saltiness. In these methods, in order to further reduce the soil salinity, it is necessary to increase the amount of applied water that this excess water, if not removed by proper drainage, will cause an increase in groundwater levels, followed by drainage problems. Although leaching of salts, one of the main objectives is to install drainage systems, but leaching other materials such as pesticides and fertilizers and entering them into surface waters is one of the biggest disadvantages of these systems (Nadri and Jafari, 2016).

The entry of these materials into surface water can cause contamination of surface waters and also creates environmental problems (Hamlin et al, 2008; Wang et al, 2009). Nitrate, as the main form of nitrogen, is directly and indirectly produced by the decomposition and biochemical changes of various mineral and organic compounds in the soil.

In recent decades, the use of nitrogen fertilizers has increased dramatically, regardless of their impact on soil characteristics, agricultural products, and especially environmental pollution. Nitrate, such as surfaces of soil colloids, has a negative charge and is easily transported by surface water and especially groundwater through rainwater or irrigation (Hashemi et al, 2011).

Seuna, and Kauppi (1980) showed that by changing the drainage system from surface to subsurface, total nitrogen and nitrate nitrogen concentrations in surface waters are strongly increased. The entry of high nitrate in the human body and the livestock and its transformation into nitrite causes impairment of oxygen transfer to the blood (methemoglobinemia) and digestive system cancer (Abedi-Koupai and Mousavi, 2004).

Several methods are used to remove nitrate pollutants from the water, but due to the high volume of agricultural drainage water and also because of the high cost of these methods, other than the biological removal method, other methods for removing nitrate from agricultural drainage water can not be used (Hashemi et al, 2011).

Denitrification is performed by a group of microorganisms that work more in an anaerobic environment (Robertson and Kuenen, 1984). Since the denitrifying bacteria are active in anaerobic conditions, it can help to increase the activity of these microorganisms by creating anaerobic conditions. But in general, this process is limited by the lack of carbon resources in subsurface soils (Cambardella et al, 1999).

For this reason, in most of these systems, by passing the contaminated water to nitrate from an environment containing carbon materials, the intensity of denitrification is increased and the nitrate is removed from contaminated water. Denitrification bioreactors are suitable option for removing 
nitrate from agricultural drainage water. One of the suitable methods for using these bioreactors is the creation of a denitrification bed. According to this method, the removal of nitrate occurs through the formation of beds in the field and at the outlet location and filling them with carbon materials and passing drainage water through them.

Blowes et al. (1994) in the field by making bioreactor containing a mixture of sand, bark of trees, wood particles and leaves of trees, observed that during one year of operation, the system could eliminate all nitrate nitrogen from drainage water with a flow rate of 10 to 60 liters per day and a concentration between 3 and $6 \mathrm{mg}$ per liter.

The researchers also said that the variation in the EC of the outflow from the denitrification bioreactor and the EC of the water supply source is not appreciable. Hernandez-Apaolaza and Guerrero (2008) concluded that changes in EC during the study period were not significant. The results of moghimi et al. (2016) showed that there is a significant difference between the amount of EC of the outlet water from the denitrification bioreactor and the EC of the water supply source. The objectives of this study was to investigate the effect of different hydraulic cross sections of denitrification beds on the amount of effluent EC.

\section{MATERIALS AND METHODS}

The study was conducted in the years 2016 and 2017 at the research farm of college of Aburaihan, university of Tehran, located in Pakdasht, Iran. The research area located at 25 kilometers south-east of Tehran, at latitude 33 degrees north and longitude 51 degrees east and 1180 meters above sea level.

The climate of Pakdasht is considered as aried and semi-arid, but its northern parts are mild due to high altitudes. The average annual rainfall is $170 \mathrm{~mm}$ per year. The average annual temperature is approximately $16.8^{\circ} \mathrm{C}$. and its annual evapotranspiration is more than the average annual rainfall.

In this study, three beds with rectangular, triangular and semicircular cross section were designed and constructed. The depth and volume of the bed made the same and were $0.6 \mathrm{~m}$ and 0.7 $\mathrm{m}^{3}$ respectively. Details of the dimensions of the denitrification beds are given in Tables 1, 2 and 3 .

Table 1- Dimensions of the denitrification bed with triangular cross-section

\begin{tabular}{|c|c|c|c|}
\hline Volume $\left(\mathrm{m}^{3}\right)$ & Depth $(\mathrm{m})$ & Angle $\left({ }^{\circ}\right)$ & Length $(\mathrm{m})$ \\
\hline 0.7 & 0.6 & 60 & 3.5 \\
\hline
\end{tabular}

Table 2- Dimensions of the denitrification bed with semicircular cross-section

\begin{tabular}{|c|c|c|c|}
\hline Volume $\left(\mathrm{m}^{3}\right)$ & Depth $(\mathrm{m})$ & Radius $(\mathrm{m})$ & Length $(\mathrm{m})$ \\
\hline 0.7 & 0.6 & 0.6 & 1.25 \\
\hline
\end{tabular}

Table 3- Dimensions of the denitrification bed with rectangular cross-section 
Revista Tecnologia e Ambiente, v. 25, 2019, Criciúma, Santa Catarina/SC ISSN Eletrônico 2358-9426 e ISSN Impresso 1413-8131

\begin{tabular}{|c|c|c|c|}
\hline Volume $\left(\mathrm{m}^{3}\right)$ & Depth $(\mathrm{m})$ & Width $(\mathrm{m})$ & Length $(\mathrm{m})$ \\
\hline 0.7 & 0.6 & 0.78 & 1.5 \\
\hline
\end{tabular}

Source: Author, 2019

After creating beds, in order to prevent the seepage, inside the beds covered with concrete and then it was waterproofing. Then these beds were filled with wood chips of beech tree. The volume of wood chips used in the three denitrification bed was the same. After filling all the beds from the wood chips of beech tree, it was covered with plastics. Figure 1 shows the denitrification beds before filling and afterwards. Two tubes of 1 inch diameter were placed at a depth of 25 and $50 \mathrm{~cm}$ from the bottom of the bed as an outlet.

Figure 1-Denitrification beds before and after filling
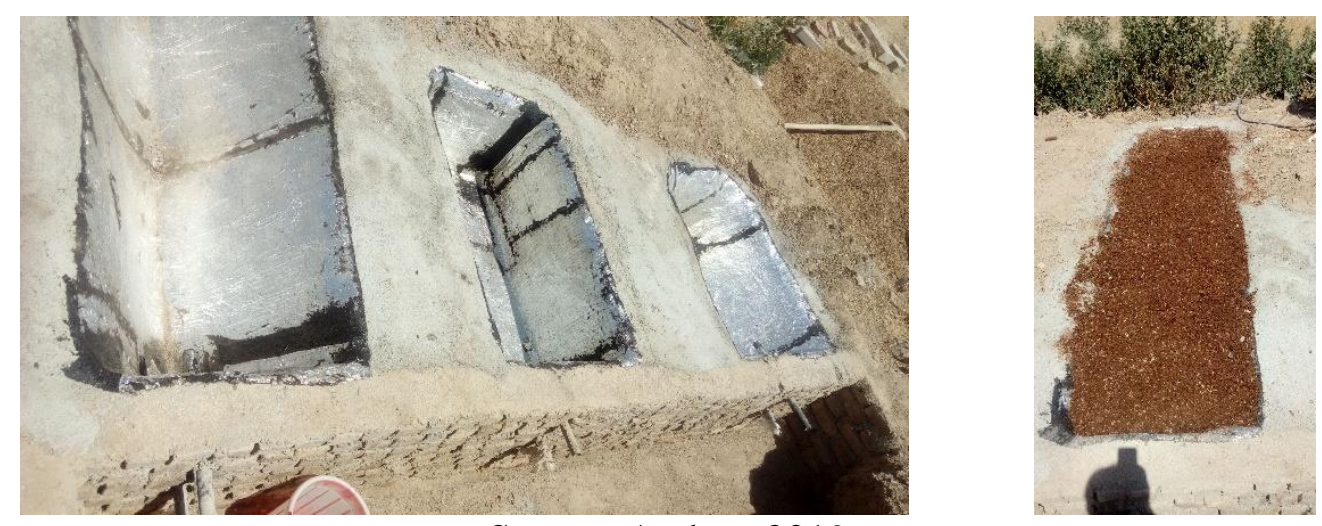

Source: Author, 2019

A 1000-liter reservoir was used to enter the water into denitrification beds. Water was entered into each of the beds continuously and permanently with constant intensity, and exits from the outlets at the end of the bed. Table 4 shows the results of chemical analysis of inflow to the beds. Samples were taken from the outlets of all three beds at a depth at 25 and $50 \mathrm{~cm}$ from the bottom of the bed for two months. EC of the samples was read using EC-meter (780 EC meter-Metrohm).

Table 4-Results of chemical analysis of inflow to the beds

\begin{tabular}{|c|c|}
\hline Parameter & Amount \\
\hline Nitrate (mg/lit) & 33.2 \\
\hline Ammonium (mg/lit) & 0.0056 \\
\hline Chlorine (meq/lit) & 6.4 \\
\hline Carbonate (meq/lit) & 0 \\
\hline Bicarbonate (meq/lit) & 3.92 \\
\hline Phosphorus (mg/lit) & $<0.1$ \\
\hline Potassium (mg/lit) & 5 \\
\hline potential of Hydrogen & 7.42 \\
\hline
\end{tabular}

Source: Author, 2019

The data of the experiment were subjected to analysis of variance (ANOVA) using univariate test at the significance level of 0.05 in SPSS16 software. 


\section{RESULTS AND DISCUSSION}

Figure 2 shows the trend of variations in the EC at a depth of $25 \mathrm{~cm}$ from the floor of the denitrification bed for the input and output flow to the denitrification bed throughout the experiment period. As shown as in this figure, the EC of the outflow from the denitrification bed with a triangular cross-section fluctuates between 727.8 to $1070 \mu \mathrm{s} / \mathrm{cm}$.

The EC of the outlet stream from the denitrification bed with a rectangular cross-section changes from 702.6 to $1080 \mu \mathrm{s} / \mathrm{cm}$. The EC of the outflow of denitrification bed with a semicircular cross section during the study period was between 775.6 to $1080 \mu \mathrm{s} / \mathrm{cm}$. At the same time, the variation in the EC of the inflow into the denitrification bed fluctuated from 695.4 to $970.7 \mu \mathrm{s} / \mathrm{cm}$. According Figure 2, the EC of the outflow from the denitrification beds has an increased in all treatments during the study.

Figure 2- The process of changes in the EC over time and at a depth of $25 \mathrm{~cm}$

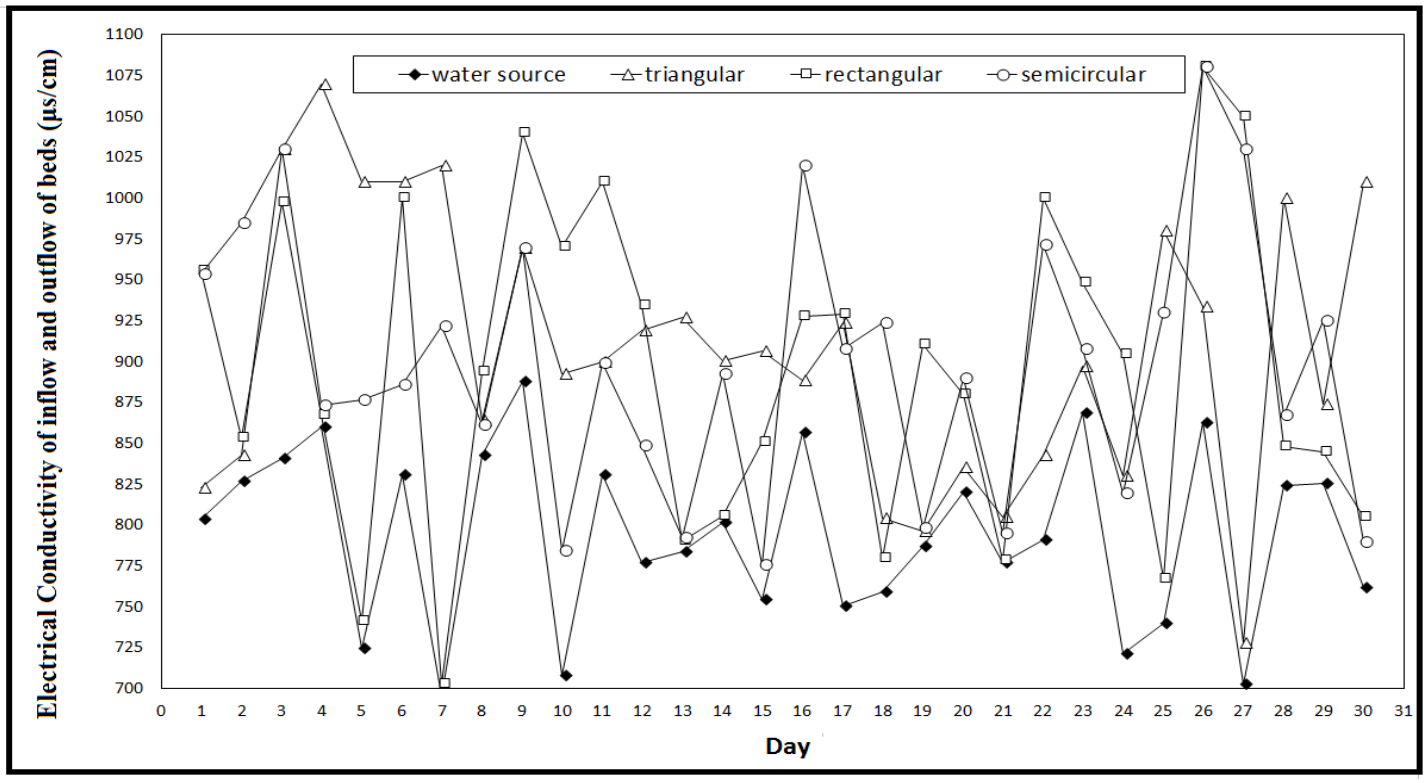

Source: Author, 2019

Figure 3 shows the trend of variations in the EC at a depth of 50 in denitrification bed in the inflow and outflow throughout the experiment period. As shown in this figure, the EC of the outflow from the denitrification beds with a triangular, rectangular, and semicircular cross section at a depth of $50 \mathrm{~cm}$ from the floor of the denitrification bed was fluctuates between 805.6 to $1398,800.11$ to 1392.4, and 811.4 to $1392 \mu \mathrm{s} / \mathrm{cm}$, Respectively.

At the same time, the variation in the EC of the inflow into the denitrification bed fluctuated from 800.3 to $1294 \mu \mathrm{s} / \mathrm{cm}$. As shown in Fig. 3, the EC of the outflow from the denitrification beds has an increasing trend compared to the amount of EC of the inflow into the denitrification beds. 
Figure 3- The process of changes in the EC over time and at a depth of $50 \mathrm{~cm}$

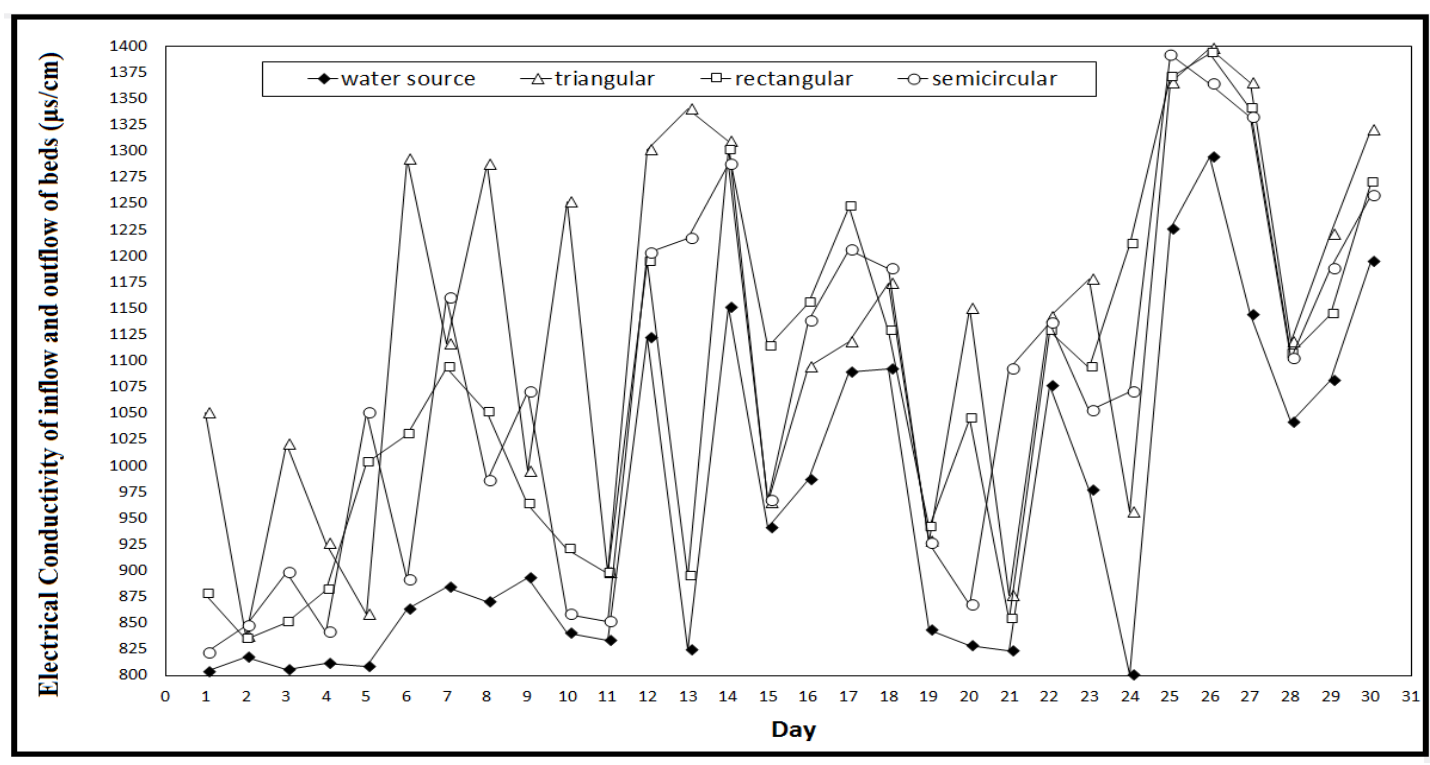

Source: Author, 2019

Tables 5 and 6 shows the results of paired t-test for the measured EC of inflow into to the triangular, rectangular, and semicircular denitrification beds and their outflow at depths of 25 and 50 $\mathrm{cm}$. The results of paired t-test for the amount of EC of inflow denitrification beds and their outflow at depths of 25 and $50 \mathrm{~cm}$ show that decision criteria is less than 0.05 and it can be said that there is a significant difference between the measured EC of inflow and outflow.

Table 7 shows the results of the Univariate test. According this table, the effect of the type of denitrification bed, the criterion of decision 0.04 is obtained, since this value is less than 0.05 . So the zero assumption that the effect of three types of denitrification beds is equal to the EC of the flow is rejected.

Therefore, it can be mentioned that the EC of the outflow in the three denitrification beds is not the same, in contrast to the equalization of the EC of the inflow into them, due to the difference in their hydraulic cross section. The results for the effect of the two depths on the EC of the outflow from the denitrification beds also indicate that the criterion value of the decision is calculated 0 and since this value is less than 0.05 , then the zero assumption that the effect of both depths is equal to the amount of variation of EC in the outflow is rejected.

Table 5- Paired t-test results for the measured EC of the input to the beds and output from them

\begin{tabular}{|c|c|c|c|c|c|c|c|c|}
\hline $\begin{array}{c}\text { Type of cross } \\
\text { section beds }\end{array}$ & Mean & $\begin{array}{c}\text { Std. } \\
\text { deviation }\end{array}$ & $\begin{array}{c}\text { Std. Error } \\
\text { Mean }\end{array}$ & Lower & Upper & $\mathrm{t}$ & $\mathrm{df}$ & $\begin{array}{c}\text { Sig. (2- } \\
\text { tailed) }\end{array}$ \\
\hline Triangular bed & 89.913 & 16.415 & -143.074 & - & - & - & 29 & .000 \\
\hline Rectangular bed & 91.156 & 16.642 & -131.311 & - & - & - & 29 & .000 \\
\hline
\end{tabular}


Revista Tecnologia e Ambiente, v. 25, 2019, Criciúma, Santa Catarina/SC ISSN Eletrônico 2358-9426 e ISSN Impresso 1413-8131

\begin{tabular}{|c|c|c|c|c|c|c|c|c|}
\hline Semicircular bed & 78.468 & 14.326 & -131.124 & - & - & - & 29 & .000 \\
\hline
\end{tabular}

Table 6- Paired t-test results for the measured EC of the input to the beds and output from them

\begin{tabular}{|c|c|c|c|c|c|c|c|c|}
\hline $\begin{array}{l}\text { Type of cross } \\
\text { section beds }\end{array}$ & Mean & $\begin{array}{c}\text { Std. } \\
\text { deviation }\end{array}$ & $\begin{array}{l}\text { Std. Error } \\
\text { Mean }\end{array}$ & Lower & Upper & $\mathrm{t}$ & df & $\begin{array}{l}\text { Sig. (2- } \\
\text { tailed) }\end{array}$ \\
\hline Triangular bed & $-\overline{164.1}$ & 135.280 & 24.698 & $\begin{array}{c}- \\
214.584 \\
\end{array}$ & 113.555 & $\begin{array}{c}- \\
6.643 \\
\end{array}$ & 29 & .000 \\
\hline Rectangular bed & $\begin{array}{c}- \\
116.4\end{array}$ & 83.205 & 15.191 & $\begin{array}{c}- \\
147.539\end{array}$ & -85.400 & $\begin{array}{c}- \\
7.667\end{array}$ & 29 & .000 \\
\hline Semicircular bed & $\begin{array}{c}- \\
113.4 \\
\end{array}$ & 96.958 & 17.702 & $\begin{array}{c}- \\
149.698\end{array}$ & -77.288 & $\begin{array}{c}- \\
6.411 \\
\end{array}$ & 29 & .000 \\
\hline
\end{tabular}

Table 7- The results of the study of the effect of depth and shape of denitrification bed on the EC

\begin{tabular}{|c|c|c|c|c|c|}
\hline Source & Type III Sum of Squares & Df & Mean Square & F & Sig \\
\hline Corrected Model & $1.964 \mathrm{E} 6 \mathrm{a}$ & 5 & 392838.512 & 15.032 & .000 \\
\hline Intercept & $1.797 \mathrm{E} 8$ & 1 & $1.797 \mathrm{E} 8$ & $6.877 \mathrm{E} 3$ & .000 \\
\hline Bed kind & 171959.384 & 2 & 85979.692 & 3.290 & .040 \\
\hline Depth kind & 1656823.550 & 1 & 1656823.550 & 63.398 & .000 \\
\hline Bed kind * Depth kind & 135409.625 & 2 & 67704.812 & 2.591 & .040 \\
\hline Error & 4547239.719 & 174 & 26133.562 & & \\
\hline Total & $1.862 \mathrm{E} 8$ & 180 & & & \\
\hline Corrected Total & 6511432.277 & 179 & & & \\
\hline
\end{tabular}

Source: Author, 2019

The results show that, there is a significant difference between the measured EC in two depths of 25 and $50 \mathrm{~cm}$ in the denitrification beds. Research has shown that one of the causes of increase, decrease and no change in the amount of EC in denitrification bioreactors is the type of carbon material used in them. Khezripour et al. (2016) investigated the effect of plant residues (oak leaf powder, woodchips and rice bran) on the EC characteristics of Yasuj urban wastewater.

The results showed that application of plant residues on the amount of EC changes in Yasuj urban wastewater was significant at 5\% level and this parameter was significantly reduced. Noori et al. (2017) investigated the effects of adding alfalfa residue and two types of biochar produced from bagasse sugarcane and walnut shell on the EC of sodic and saline-sodic soils. The results showed that the application of alfalfa residue and biochar produced from bagasse walnut shell significantly increased the EC of saturated extract in both soil types.

On the other hand, the use of biochar produced from sugarcane bagasse caused a slight and non-significant increase in EC in the sodic soil a non-significant decrease in this property in salinesodic soil. Ansari et al. (2016) used barley straw as an organic filter to reduce nitrate drainage water and also investigated the effect of denitrification on the EC. 
The results showed that the concentration of nitrate in drainage water decreased for all treatments by increasing the percentage of barley straw, duration and different intensities dependent on treatments. Changes in the amount of EC during the time for any of the treatments are not particular trend, but in all cases, it follows the changes in the inflow (source).

The results of analysis of variance of data on the amount of EC of water drainage outflow from different treatments showed that none of the sources of variation caused a significant difference between treatments. Babaei-Moghadam et al. (2015) studied the ability of four types of biofilters consists of wood sawdust, rice husk, charcoal and tea wastes to reduce nitrate to reduce nitrate of drain water from paddy fields., and also investigated the effect of denitrification on the EC. The results showed that biofilter of tea decreased the nitrate content during the study period, but this was not significant and also increased the EC of the outflow compared to the inflow, but this increase was not significant.

The results of the biofilter of rice husk information showed that there was no significant difference in the EC between the outflow and inflow to the biofilter of rice husk. Also, the amount of nitrate during the studied period did not significant difference but slightly decreased. The results of the biofilter of charcoal showed that nitrate levels decreased during the studied period, but this was not significant. Also, the amount of EC in the outflow from the biofilter of charcoal has slightly decreased, but this difference is not significant.

The results of the biofilter of wood sawdust information indicated that the wood sawdust absorbent decreased the nitrate amount during the study period, but this was not significant. The amount of EC in the outflow of the biofilter of wood sawdust is slightly lower, but this difference is not significant. Mirzaei-Takhtgahi and Ghamarnia (2017) studied the effect of vermicompost on soil EC. The results showed that the use of vermicompost did not have a significant effect on EC of soil, but the use of vermicompost increased the EC of soil in the first layer by 26.98 and in the second layer, 0.8\%, compared to the control treatment. Abadi et al (2012) and Srikanth et al (2000) in their study concluded that the application of vermicompost significantly increased the EC of the soil. Atieh et al. (2000) in result of their experiments found that consumption of 5, 10, 25, 50 and 100\% of vermicompost in the common culture beds caused a linear increase in EC with increasing vermicompost content. Parthasarathi et al. (2008) concluded that with the use of vermicompost, the EC of the soil increased.

Ouni et al. (2014) also observed that the EC in soil increased proportionally with increasing concentrations level of organic matter compost application in saline soil. Abrishamkesh et al. (2015) also reported that adding the amount of rice biochar to an alkaline soil increased the amount of EC of the soil. Also, it is necessary to note that the concentration level of carbon material application is one 
Revista Tecnologia e Ambiente, v. 25, 2019, Criciúma, Santa Catarina/SC ISSN Eletrônico 2358-9426 e ISSN Impresso 1413-8131

of the important factors that affects their efficacy, so that sometimes the change in the concentration level of carbon material application leads to completely different results (Song et al., 2014). Some other studies show that organic matter decomposition in denitrification beds can cause increases EC. Moez Ardalan and Savaghebi-Firoozabadi (2016) reported that there are elements such as magnesium, calcium, potassium, phosphorus and sulfur in the structure of organic matter, which increases EC during decomposition of organic matter. Huang et al. (2004) reported that increased EC could be due to the release of mineral salts such as phosphates and ammonium ions through organic matter decomposition.

Rousta et al. (2002) reported that the degradation of various organic matter in the soil to various elements and compounds increased the electrolyte concentration of the soil and, consequently, increased EC in the soil. Li et al. (2017) to remove nitrate from groundwater from wood chips and sulfur used in a denitrification wall. The results showed that during the removal of nitrate, a small amount of nitrite and ammonium were produced which increased the EC of water. David et al. (2016) to remove nitrate from drainage water by a denitrification bioreactor made of wood chips.

The results showed that nitrite was produced during removal of nitrate. Some studies have shown that breathing of heterotrophic bacteria is produced in carbon dioxide ( $\left.\mathrm{CO}_{2}\right)$ denitrification beds and when the gas is dissolved in water, the EC of the water is increased from the denitrification beds (Healy et al, 2012; Elgood et al, 2010; Warneke et al, 2011). Some studies show that, during the process of denitrification, Methane $\left(\mathrm{CH}_{4}\right)$, Nitrogen oxide $\left(\mathrm{N}_{2} \mathrm{O}\right)$ and Hydrogen sulfide $\left(\mathrm{H}_{2} \mathrm{~S}\right)$ are produced in the denitrification beds, when these gases are dissolved in water, the EC of the water increases (Herbstritt, 2014; Warneke et al, 2011; Elgood et al, 2010; Healy et al, 2012).

\section{CONCLUSIONS}

The results showed that the shape of the cross-section of the denitrification beds and the depth were two factors affecting the changes in the EC. Also, the results showed that the EC of the outflow of the denitrification beds in both depths of 25 and $50 \mathrm{~cm}$ had a significant difference by the EC of the inflow. Also the amount of EC of outflow in denitrification beds had an increasing trend compared to the EC of the inflow in all treatments. According to the results of this research, the following suggestions for the continuation of the research are presented:

1. Investigating the variations in the $\mathrm{EC}$ of the outlet water from the denitrification beds for a longer time (more than two months).

2. Investigating the effect of the influent nitrate concentration on the amount of EC of the outlet water from the denitrification beds. 
3. Investigating the effect of particle size of carbon materials used in beds on the amount of EC of the outlet water from the denitrification bed.

4. Investigating the effect of other carbon materials on the $\mathrm{EC}$ of the outlet water from the denitrification beds.

5. Investigate the application of water $\mathrm{EC}$ reducing materials in denitrification beds.

6. Investigating the effect of water EC reducing materials on other chemical properties of water.

7. Investigating the effect of different hydraulic cross sections of denitrification beds on the performance of water EC reducing materials.

\section{REFERENCES}

Abadi, Z. A., Sepanlou, M. G., \& Alashti, S. R. (2012). Effect of vermicompost on physical and chemical properties of soil. JWSS-Isfahan University of Technology, 15(58), 125-137.

Abedi-Koupai, J., \& Mousavi, S. F. (2004). Lead Adsorption from Industrial Wastewater Using Rice Husk Ash. Journal of Water \& Wastewater,14(4), 17-24.

Abrishamkesh, S., Gorji, M., Asadi, H., Bagheri-Marandi, G. H., \& Pourbabaee, A. A. (2015). Effects of rice husk biochar application on the properties of alkaline soil and lentil growth. Plant, Soil and Environment, 61(11), 475-482.

Ansari, S., Heidarpour, M., Mousavi, S. (2016). A Study of Effect of Barley Straw as Organic Filter on Reduction of Drainage Water Nitrate. Iranian Water Research Journal, 9(20), 87-96.

Atiyeh, R. M., Edwards, C. A., Subler, S., \& Metzger, J. D. (2000). Earthworm-processed organic wastes as components of horticultural potting media for growing marigold and vegetable seedlings. Compost Science \& Utilization, 8(3), 215-223.

Babaei-Moghadam, A., Khaledian, M., hahnazari, A., Mortezapour, M. (2015). Effect of four natural absorbers to reduce nitrate, phosphate, $\mathrm{EC}, \mathrm{pH}$ and water temperature of drain water from paddy fields. Iranian Journal of Irrigation \& Drainage, 9(5), 798-810.

Blowes, D. W., Robertson, W. D., Ptacek, C. J., \& Merkley, C. (1994). Removal of agricultural nitrate from tile-drainage effluent water using in-line bioreactors. Journal of Contaminant Hydrology, 15(3), 207-221.

Cambardella, C. A., Moorman, T. B., Jaynes, D. B., Hatfield, J. L., Parkin, T. B., Simpkins, W. W., \& Karlen, D. L. (1999). Water quality in Walnut Creek watershed: Nitrate-nitrogen in soils, subsurface drainage water, and shallow groundwater. Journal of Environmental Quality, 28(1), 2534.

David, M. B., Gentry, L. E., Cooke, R. A., \& Herbstritt, S. M. (2016). Temperature and substrate control woodchip bioreactor performance in reducing tile nitrate loads in east-central Illinois. Journal of environmental quality, 45(3), 822-829.

Elgood, Z., Robertson, W. D., Schiff, S. L., \& Elgood, R. (2010). Nitrate removal and greenhouse gas production in a stream-bed denitrifying bioreactor. Ecological engineering, 36(11), 1575-1580. Hamlin, H. J., Michaels, J. T., Beaulaton, C. M., Graham, W. F., Dutt, W., Steinbach, P., \& Main, K. L. (2008). Comparing denitrification rates and carbon sources in commercial scale upflow denitrification biological filters in aquaculture. Aquacultural engineering, 38(2), 79-92.

Hashemi, S., Heidarpour, M., Mostafazadeh-Fard, B. (2011). Investigation of Nitrate Removal in Two Forms of Biofilter Position in Subsurface drainage systems. Irrigation Sciences and Engineering, 34(2), 71-82.

Healy, M. G., Ibrahim, T. G., Lanigan, G. J., Serrenho, A. J., \& Fenton, O. (2012). Nitrate removal rate, efficiency and pollution swapping potential of different organic carbon media in laboratory denitrification bioreactors. Ecological Engineering, 40, 198-209. 
Herbstritt, S. (2014). Environmental tradeoffs of denitrifying woodchip bioreactors. Graduate Dissertations and Theses at Illinois, University of Illinois at Urbana-Champaign.

Hernandez-Apaolaza, L., \& Guerrero, F. (2008). Comparison between pine bark and coconut husk sorption capacity of metals and nitrate when mixed with sewage sludge. Bioresource technology, 99(6), 1544-1548.

Huang, G. F., Wong, J. W. C., Wu, Q. T., \& Nagar, B. B. (2004). Effect of C/N on composting of pig manure with sawdust. Waste management, 24(8), 805-813.

Khezripour, R., Rahimi, A., Moradi, A., \& Hosseini, F. (2016). Effect of plant residues on electrical conductivity, $\mathrm{PH}$, dissolved oxygen and soluble solids content of urban waste water in Yasuj. Second National Congress on the Development and Promotion of Agricultural Engineering and Soil Science of Iran, Association for the Promotion of Basic Sciences and Techniques, Tehran, Iran.

Li, R., Feng, C., Xi, B., Chen, N., Jiang, Y., Zhao, Y., ... \& Zhao, B. (2017). Nitrate removal efficiency of a mixotrophic denitrification wall for nitrate-polluted groundwater in situ remediation. Ecological Engineering, 106, 523-531.

Mirzaei-Takhtgahi, H., \& Ghamarnia, H. (2017). The effect of Vermicompost on soil electrical conductivity. Fourth International Conference on Environmental Planning and Management. Tehran, Faculty of Environment, University of Tehran, Iran.

Moez Ardalan, M. \& Savaghebi-Firoozabadi, G. R. (2016). Soil fertility management for sustainable agriculture. Tehran University Press and Publishing, Tehran, Iran.

Moghimi, N., Naseri, A., Soltani Mohammadi, A., Garm Dareh, S. (2016). Evaluation of Bagasse on Nitrate Reduction from Effluent Subsurface Drainage Water. Irrigation Sciences and Engineering, 39(2), 49-58.

Nadri, F. \& Jafari, H. (2016). Investigation of nitrate ion contamination in groundwater resources of Aleshtar plain aquifer. Eighth National Conference and Specialized Exhibition of Environmental Engineering, Iran Environmental Engineering Society, Tehran, Iran.

Noori, Z., Delavar, M.A., \& Safari, Y. (2017). The effects of two biochars and alfalfa residues on electrical conductivity of a sodic and a saline-sodic soil. The 15th Iranian Soil Science Congress, Isfahan, Soil Science Association of Iran, Isfahan University of Technology, Iran.

Ouni, Y., Lakhdar, A., Scelza, R., Scotti, R., Abdelly, C., Barhoumi, Z., \& Rao, M. A. (2013). Effects of two composts and two grasses on microbial biomass and biological activity in a salt-affected soil. Ecological engineering, 60, 363-369.

Parthasarathi, K., Balamurugan, M., \& Ranganathan, L. S. (2008). Influence of vermicompost on the physico-chemical and biological properties in different types of soil along with yield and quality of the pulse crop-blackgram. Journal of Environmental Health Science \& Engineering, 5(1), 51-58.

Robertson, L. A., \& Kuenen, J. G. (1984). Aerobic denitrification-old wine in new bottles? Antonie van Leeuwenhoek, 50(5-6), 525-544.

Rousta, M.J., Golchin, A., Siadat, H., \& Saleh Rastin, N. (2002). Effects of Organic Matter and Mineral Compounds on Some Chemical Properties and Biological Activity of a Sodic Soil. Iranian journal of soil and waters sciences, 16(1), 33-45.

Seuna, P., \& Kauppi, L. (1981). Influence of sub-drainage on water quantity and quality in a cultivated area in Finland. Publications of the Water Research Institute, National Board of Waters, Finland, No. 43.

Song, Y., Zhang, X., Ma, B., Chang, S. X., \& Gong, J. (2014). Biochar addition affected the dynamics of ammonia oxidizers and nitrification in microcosms of a coastal alkaline soil. Biology and fertility of soils, 50(2), 321-332.

Srikanth, K., Srinivasamurthy, C. A., Siddaramappa, R., \& Parama, V. R. (2000). Direct and residual effect of enriched composts, FYM, vermicompost and fertilizers on properties of an Alfisol. Journal of the Indian Society of Soil Science, 48(3), 496-499.

Wang, Q., Feng, C., Zhao, Y., \& Hao, C. (2009). Denitrification of nitrate contaminated groundwater with a fiber-based biofilm reactor. Bioresource Technology, 100(7), 2223-2227. 
Revista Tecnologia e Ambiente, v. 25, 2019, Criciúma, Santa Catarina/SC ISSN Eletrônico 2358-9426 e ISSN Impresso 1413-8131

Warneke, S., Schipper, L. A., Bruesewitz, D. A., \& Baisden, W. T. (2011). A comparison of different approaches for measuring denitrification rates in a nitrate removing bioreactor. Water research, 45(14), 4141-4151. 